Research Article

\title{
Wintering of Leaf Warblers (Phylloscopus Boie, 1826) in Gangajalghati: First Photographic Evidence of Four Species from Northern Bankura, West Bengal, India
}

\author{
Ananya Nayak \\ Department of Zoology, Bankura Sammilani College, Bankura 722102, West Bengal, India
}

Article history:

Submission May 2021

Revised June 2021

Accepted June 2021

*Corresponding author:

E-mail: ananya0001@gmail.com

\begin{abstract}
Leaf warblers are small insectivorous passerine birds that belong to the genus Phylloscopus (Boie, 1826) and exhibit great similarity in plumage and morphology. These songbirds have been reported with the maximum diversity in the eastern Himalayas and southern China. No comprehensive studies with photographic evidence on Phylloscopus have been conducted so far in the Southern parts of West Bengal, including Bankura district in India. Three types of habitats of Gangajalghati village in Bankura district were surveyed during winter for 8 months between November 2015 and February 2017 and bird counts were recorded and photographed. A total of 49 individuals from four species of Phylloscopus were recorded. The most abundant species recorded in the study was the dusky warbler (Phylloscopus fuscatus, Blyth, 1842) followed by greenish warbler (Phylloscopus trochiloides, Sundevall, 1837), common chiffchaff (Phylloscopus collybita, Vieillot, 1817) and Hume's leaf warbler (Phylloscopus humei, Brooks, 1878). Further, the prey abundance of leaf warblers (lepidopteran caterpillar and other arthropods) were determined in the early winter session (first week of November and December). The study recorded maximum bird abundance and species richness in the wetland associated habitats with higher prey abundance followed by barren land and agriculture field. The work documented the visit of dusky and greenish warblers to Bankura for the first time in the past 40 years and recorded the wintering of common chiffchaff and Hume's leaf warblers as the first evidence from the district.
\end{abstract}

Keywords: Bankura, Gangajalghati, Phylloscopus, Prey abundance, West Bengal, Wetland, Wintering

\section{Introduction}

Leaf warblers are small insectivorous passerine birds that belong to the genus Phylloscopus (Boie, 1826), family Phylloscopidae and order Passeriformes [1]. These Old World leaf warblers exhibit great similarity in plumage and morphology, making it very difficult to observe and identify these accurately in the wild [2-3]. They have been observed throughout the Old World, from Europe, Australasia, and Africa, with the maximum diversity in the eastern Himalayas and southern China, where up to 16 species may occur along with altitudinal gradients and at least 20 species in the Qinling mountains in north-central China [12]. These canopy-dwelling songbirds are adapted to a wide range of ecosystems in Asia and in some localities of the western Himalayas they might comprise up to $40 \%$ of the bird population [4].

The total number of recognised species under the genus Phylloscopus has increased significantly in the past three decades, with a total of 77-78 species at present and the majority of these species are found in Asia [1,3]. Both migratory and resident populations of classic leaf warblers have been reported worldwide with more migratory populations from northerly breeding species and more resident or short distance migrants from southern breeders $[1,5,6]$.

A large number of studies have reported these

\section{How to cite:}

Nayak A (2022) Wintering of Leaf Warblers (Phylloscopus Boie, 1826) in Gangajalghati: First photographic evidence of four species from Northern Bankura, West Bengal, India. Journal of Tropical Life Science 12 (1): 123 - 129. doi: 10.11594/jtls.12.01.13. 
migratory birds in almost all the states of India including Jammu \& Kashmir, Himachal Pradesh, Madhya Pradesh, Andhra Pradesh, Bihar [7]; Uttarakhand [8]; Assam [9]; Karnataka [10]; Maharashtra [11] and others [7, 12, 13, 14] during their winter visit. A number of studies have also reported the occurrence of these songbirds in different parts of West Bengal [7, 12, 15, 16, 17]. However, no comprehensive studies with photographic evidence on Phylloscopus have been conducted so far in the Southern parts of West Bengal, including Bankura district. The present study provides first photographic evidence of regular wintering of four species of Phylloscopus (Boie, 1826) in the Gangajalghati village of Bankura district.

\section{Material and Methods}
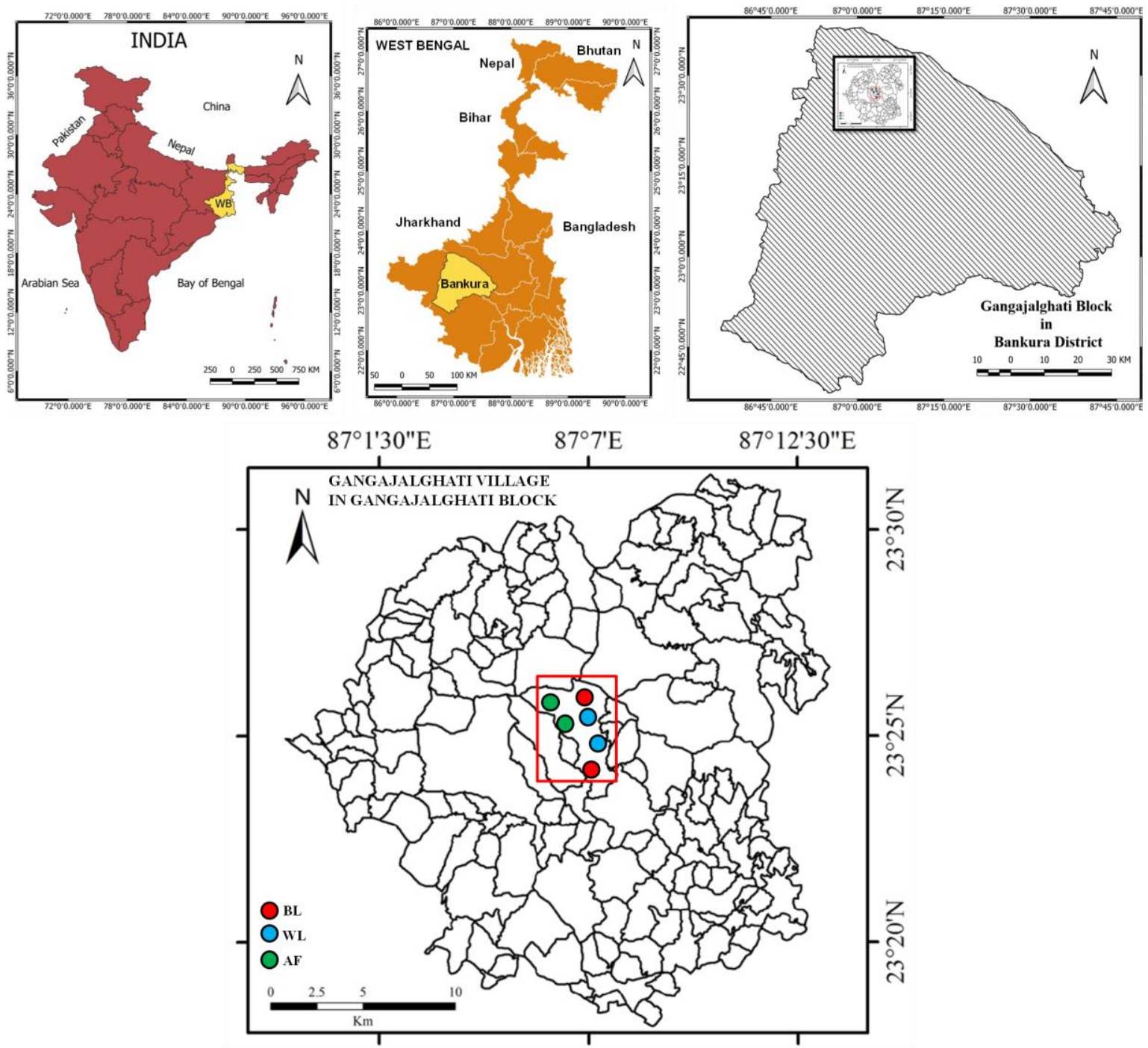

Figure 1. Geographical location of the study area: Gangajalghati village in Gangajalghati block of Bankura district, West Bengal, India. (Map data: India and West Bengal from [18] with permission from the publisher; Bankura district was generated using QGIS and modified using Gangajalghati Block map; Gangajalghati Block modified after [19]) 

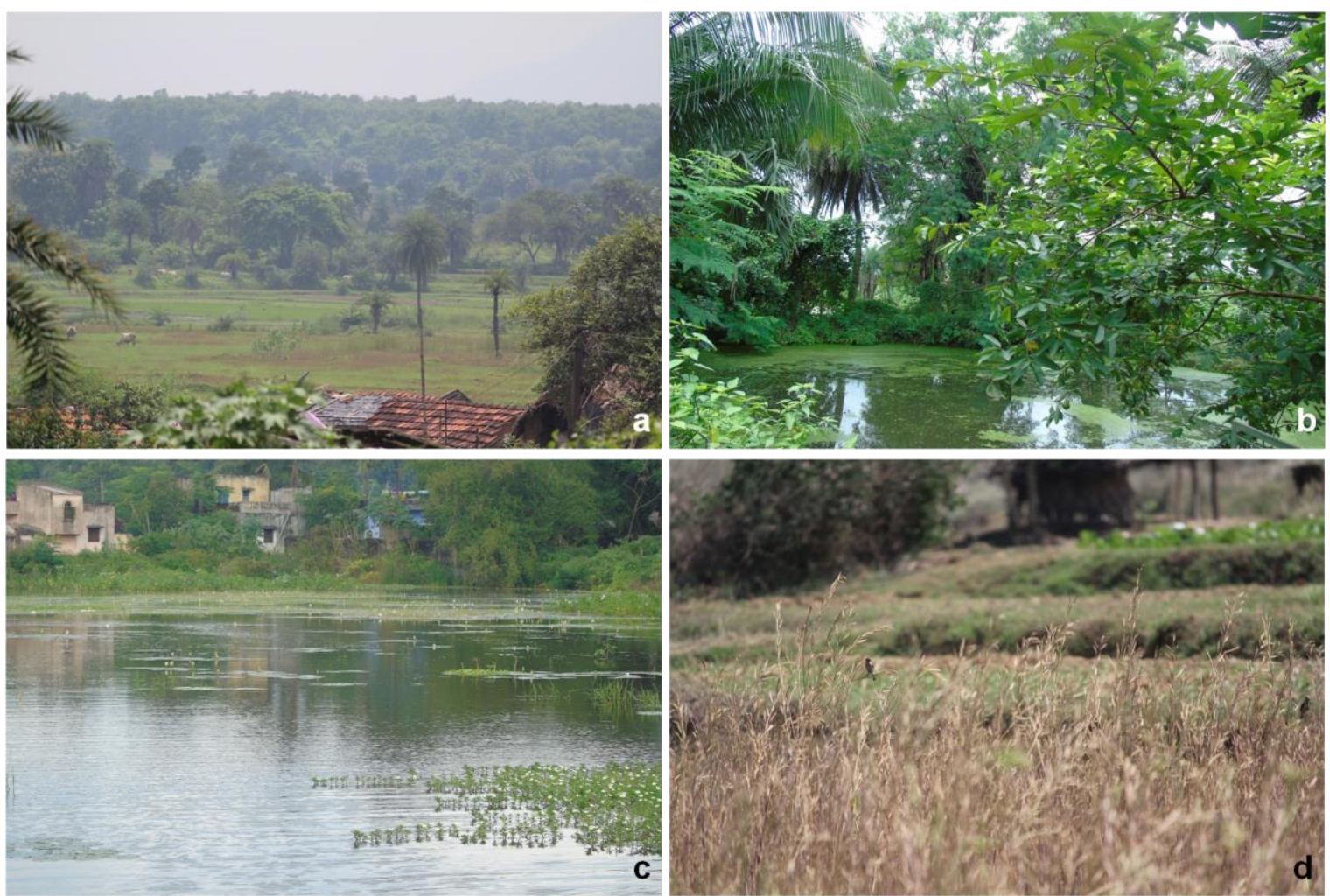

Figure 2. Habitat types surveyed in Gangajalghati Village. (Notes: a. Barren land, b \& c. Wetland with scrub vegetation and d. Agriculture Field)

an annual average rainfall in the district being $1350 \mathrm{~mm}$ [19]. The soils in the study area has been described as loamy skeletal mixed Typic Ustorthents (38.1\%), fine loamy mixed hyperthermic Ultic Paleustlafs (26.4\%) and fine loamy mixed hyperthermic Typic Haplaquepts (14\%). The monsoon season (June to September) experiences about $80 \%$ of the total rainfall [19]. Birds were observed in the following habitat types (Figure 2).

\section{Barren land}

Unused agricultural lands characterize these with brushes and grass cover interspersed with Acacia sp, Argemone mexicana, Azadirachta indica, Bambusa sp, Borassus flabellifer, Calotropis gigantea, Datura sp. Justicia adhatoda, Opuntia spp, Clerodendrum infortunatum, Phoenix sylvestris e.t.c. trees.

\section{Wetland with scrub vegetation}

These are characterized by man-made and natural water bodies with distinct vegetation assemblages dominated by Aegle marmelos, Azadirachta indica, Bambusa sp, Borassus flabellifer, Carica papaya, Cocos nucifera, Datura sp, Gmelina arborea, Haldina cordifolia, Justicia adhatoda, Moringa oleifera, Musa paradisiaca, Phoenix sylvestris, Psidium guajava, Tabernaemontana divaricata, Tamarindus indica, and Terminalia arjuna.

\section{Agriculture field}

These habitats are areas used for cultivating crops such as rice, mustard crops and some common vegetables (bottle gourd, brinjal, cabbage, carrot, cauliflower, potato, onion, radish, tomato). Besides crop plants, these lands are also colonized by a number of shrubs and weedy plants.

\section{Bird surveys and identification}

The above-mentioned habitats of Gangajalghati village were surveyed during winter for 8 months between November 2015 and February 2017. The total survey period was divided into two seasons (November 2015 to February 2016 and November 2016 to February 2017) to focus on these migratory birds. Bird counts were carried out within six squares $(250 \times 250 \mathrm{~m})$ where two such square areas represented each type of habitat. Bird observations were conducted three times per month between 7:00 to 9:00 AM and 3:00-5:00 PM devoting 20 minutes in each square each ses- 

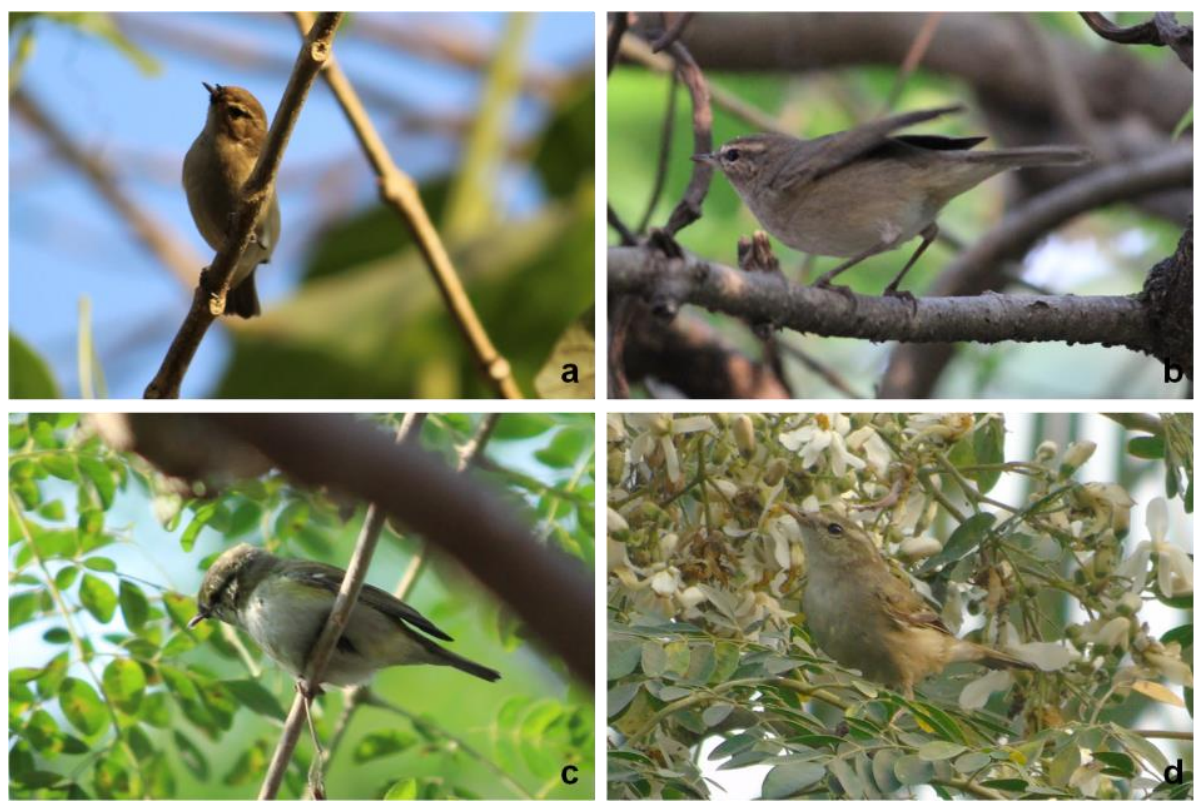

Figure 3. Leaf warblers (Phylloscopus Boie, 1826) documented in the study area. a. common chiffchaff (Phylloscopus collybita, Vieillot, 1817), b. dusky warbler (Phylloscopus fuscatus, Blyth, 1842), c. Hume's leaf warbler (Phylloscopus humei, Brooks, 1878) and d. greenish warbler (Phylloscopus trochiloides, Sundevall, 1837)

sion. Bird counts were recorded and photographed using a Canon EOS 1200D DSLR Camera with a 55-250 mm lens and a Sony DSC-H400 compact camera with 63× Optical Zoom to support further identification. During adverse weather conditions like fog, prolonged precipitation, or strong winds, no surveys were conducted. Birds were identified based on physical features with the help of field guides and reference books [20-21] as well as with the assistance of The British Trust for Ornithology.

\section{Estimation of Prey Abundance}

In order to investigate the prey abundance of leaf warblers in three different habitats, the mean abundance of lepidopteran caterpillar and other arthropods were determined in the early winter session (first week of November and December). In this study, caterpillar numbers were recorded by surveying 180 trees, 30 trees per site. It was done by striking the live branches of the tree and shrub layers and counting the numbers falling on a white plastic sheet below. Further, the caterpillar colonies on the tree trunk were photographed and counted. For determination of other arthropod abundance, light trapping was done using a high power (30-Watt) LED lamp. A total of 12 night surveys, two in each study site, were conducted The total number of all arthropods was recorded.
The survey data were analysed with Microsoft Office Excel, 2010. None of the species was captured or killed during the entire period of the study.

\section{Results and Discussion}

A total of 49 individuals from four species of Phylloscopus (Boie, 1826) were recorded in all the habitats (Figure 3). The most abundant species recorded in the study was the dusky warbler (Phylloscopus fuscatus, Blyth, 1842) followed by greenish warbler (Phylloscopus trochiloides, Sundevall, 1837), common chiffchaff (Phylloscopus collybita, Vieillot, 1817) and Hume's leaf warbler (Phylloscopus humei, Brooks, 1878) (Figure 4). Maximum species richness and mean bird abundance was recorded from the wetland associated habitats with scrub vegetation followed by barren land and agriculture field (Figure 5A).

These observations are in accordance with previous studies, which showed that some of these species (e.g. Phylloscopus collybita tristis Blyth 1843) prefer to visit marshy as well as scrubland with thorny shrubs especially reeds and sedges growing in water, groves of babul (Acacia spp.), ber (Zizyphus spp.) and Tarmarisk near about water [12]. The plants on which the birds were recorded most frequently are Datura sp. Justicia adhatoda, Moringa oleifera, Psidium guajava and 


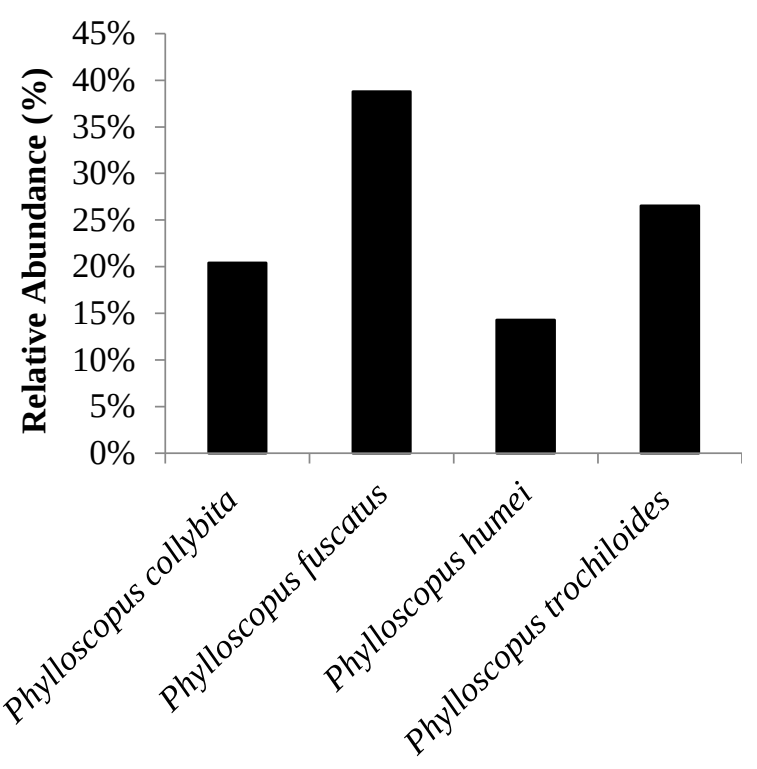

Figure 4. A relative abundance histogram for all four species of Phylloscopus observed in the present study

Tabernaemontana divaricata located near the pond-side with human habitation.

All these birds have been documented during the winter months from November to February and none were found in the other months of the year either by systematic or opportunistic screening approaches. The winter migration period recorded in this study are consistent with previous studies on leaf warblers in West Bengal [7]. The results of the prey abundance study from three habitat types demonstrated that wetland associated habitats were the most prey abundant sites followed by barren land and agriculture field (Figure 5A). These results might explain the similar individual abundance pattern in those three habitat types (Figure 5B). A number of previous studies have shown that lepidopterous larvae and other invertebrates especially arthropods constitute the bulk of the diet of migrant warbler populations [22-24]. Further, high abundance (data not shown) of chironomid larvae in the ponds of these wetland habitats might contribute to the understanding of frequent visit of all four leaf warbler species to this type of habitat. Previous studies have reported that chironomid larvae may constitute a significant part of the warbler diet including the wintering Common Chiffchaff [25-27].

Leaf warblers have body feathers of green or yellow-green color and have been observed to move frequently in the upper and middle layers of the canopy [3]. It is very difficult to determine the

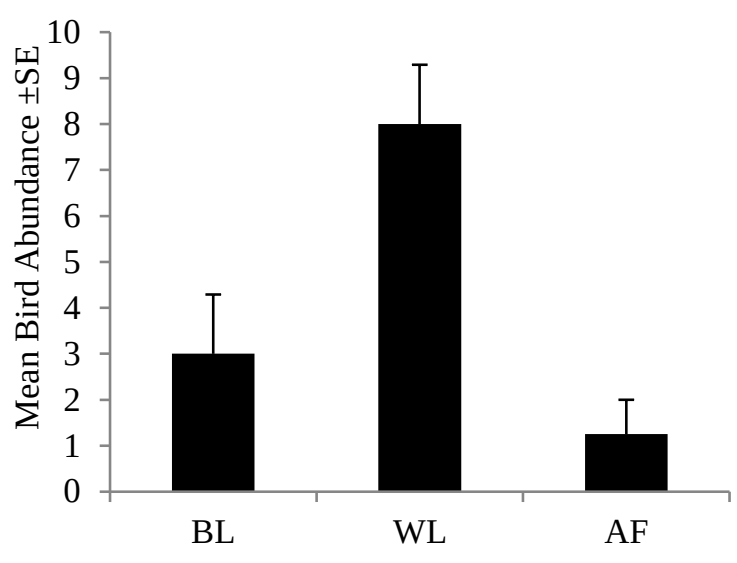

(a)

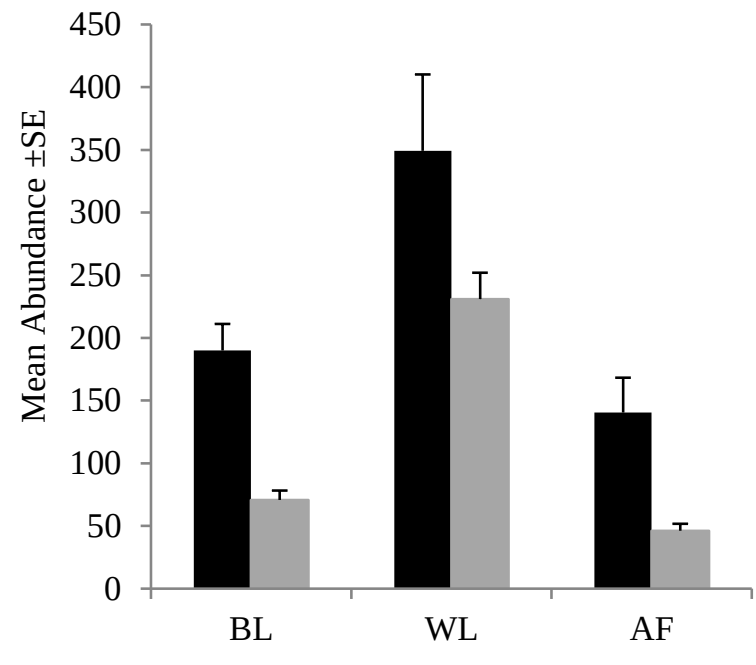

- Other Arthropods Lepidopteran Caterpillar

(b)

Figure 5. (A) Mean bird (Phylloscopus) abundance per habitat type recorded in the study area. (B) Mean prey abundance (lepidopteran caterpillar and other arthropods) per habitat type in early winter (first week of November and December of 2015 and 2016). Error bars \pm 1 standard error (SE). Total number of plants sampled: 180, 30 plants per habitat. BL: Barren land, WL: Wetland with scrub vegetation, AF: Agriculture Field.

precise diversity of these song birds due to having a large number of cryptic species in the genus Phylloscopus, exhibiting morphologically similar or identical natural populations [28]. Modern methods such as molecular genetics and song spectrogram analysis both are needed for their accurate identification and classification [3, 29]. However, being astonishingly species-rich, the genus has remained a focus of evolutionary studies to better understand ecological and evolutionary 
traits in the leaf warbler assemblage [30]. Although wintering of some these species (e.g. $P$. trochiloides) have been studied in many parts of North and South India, no such comprehensive work has been done so far about the migratory route of leaf warblers in West Bengal [13]. A number of previous studies have recognized South Bengal districts as the distribution points for these four species of Phylloscopus [2, 21]. Prior to this study, only two species of leaf warblers (P. trochiloides, Sundevall, 1837 and P. fuscatus, Blyth, 1842) have so far been reported from Bankura district by the work of Zoological Survey of India on specimen collected in the year 1979 and 1982 respectively [7]. The present study and the results of the previous study by Majumdar et al. 1992 [7] also establish that these warblers are visiting the district over the past four decades. However, to date, there is no substantive evidence on wintering of P. collybita, Vieillot, 1817 and P. humei, Brooks, 1878 from any part of the Bankura district.

The present study documented highest bird abundance and species richness in the wetland associated habitats with most prey abundance. Previous studies have shown that there is a strong association between arthropod biomass and warbler abundance and food resources constitute a strong stimulus for warblers wintering [31]. Further works have revealed a close similarity between the timing of emergence of lepidopterous larvae and the seasonal timing of bird migration [22]. The study recorded highest caterpillar abundance in $M$. oleifera, a very common tree of the wetland habitats with human habitation in the study area. The plant has previously been reported to serve as a multipurpose Indian vegetable and host of several arthropod pests including many lepidopterous larvae in the winter season [32-33]. The light-trapping detected a number of adult moths, including Noorda blitealis Walker, 1859, Eupterote molifera Walker, 1865, Helicoverpa armigera Hübner, 1808 that affect $M$. oleifera and their larvae feed voraciously on leaves and other plant parts.

\section{Conclusion}

In conclusion, the present study reports for the first time, Gangajalghati block of Bankura district as wintering ground of these beautiful song birds. Further studies are warranted to investigate the complete migratory route of these birds in Bankura and other South Bengal districts.

\section{Acknowledgement}

The author would like to record his indebtedness to Mr Nick Moran, Training Manager, The British Trust for Ornithology (BTO) and BTO for their immense help in the identification of the leaf warbler species. Further, the author would like to express his sincere thanks to Sgt. Anupran Nayak, Sergeant of Indian Air Force, Uttarlai Air Force Station, Barmer, Rajasthan for his technical support during the fieldwork of this study.

\section{References}

1. Alström P, Rheindt FE, Zhang R et al. (2018) Complete species-level phylogeny of the leaf warbler (Aves: Phylloscopidae) radiation. Molecular Phylogenetics and Evolution 126: 141-152.doi: 10.1016/j.ympev.2018.03.031.

2. Price TD (2010) The roles of time and ecology in the continental radiation of the Old World leaf warblers (Phylloscopus and Seicercus). Philosophical transactions of the Royal Society of London. Series B, Biological sciences 365 (1547): 1749-1762. doi:10.1098/rstb.2009.0269

3. Sun CH, Liu HY, Lu CH (2020) Five new mitogenomes of Phylloscopus (Passeriformes, Phylloscopidae): Sequence, structure, and phylogenetic analyses. International Journal of Biological Macromolecules 146: 638647. doi:10.1016/j.ijbiomac.2019.12.253.

4. Price T, Zee J, Jamdar K, Jamdar N (2003) Bird species diversity along the Himalayas: a comparison of Himachal Pradesh with Kashmir. Journal of Bombay Natural History Society 100: 394-409.

5. Bozó L, Csörgő T, Heim W (2021) Factors controlling the migration phenology of Siberian Phylloscopus species. Journal of Ornithology 162: 53-59. doi: 10.1007/s10336020-01805-5

6. Yong DL, Heim W, Chowdhury SU et al. (2021). The State of Migratory Landbirds in the East Asian Flyway: Distributions, Threats, and Conservation Needs. Frontiers in Ecology and Evolution 9: 1-22. doi: 10.3389/fevo.2021.613172

7. Majumdar N, Roy CS, Ghosal DK et al. (1992) In: Ghosh, A. K., (ed.). State Fauna Series 3: Fauna of West Bengal. Part 1. Calcutta, Zoological Survey of India.

8. Mohan D, Sondhi S (2017) An Updated Checklist and Bibliography of the Birds of Uttarakhand. Dehradun, Uttarakhand Forest Department.

9. Choudhury A (2006) Birds of Dibru-Saikhowa National Park and Biosphere Reserve, Assam, India. Indian Birds 2 (4): 95-105.

10. Aravind NA, Srinivasan M, Rao D (2001) Additions to the birds of Biligiri Rangaswamy Temple Wildlife Sanctuary, Western Ghats, India. Zoos' Print Journal 27: 541547. doi: 10.11609/JoTT.ZPJ.16.7.541-7.

11. Praveen J (2007) More wintering sites for the Near-threatened Tytler's Leaf-Warbler Phylloscopus tytleri in Peninsular India. Indian Birds 3 (4): 146-149.

12. Mukherjee AK (1995) Birds of arid and semi-arid tracts. Series Ed: DIRECTOR, Zoological Survey of India. Records of the Zoological Survey of India. Occasional Paper, 142. Calcutta, Zoological Survey of India. 
13. Katti M, Price TD (2003) Latitudinal trends in body size among over-wintering leaf warblers (genus Phylloscopus). Ecography 26: 69-79. doi:10.1034/j.16000587.2003.03264.x.

14. Dhyey S, Shah K, Mekola R (2021) Presence of Sichuan leaf Warblers Phylloscopus forresti in Anjaw District, Arunachal Pradesh. Indian BIRDS 17(1): 15-17.

15. Olsson U, Alström P, Ericson PGP, Sundberg P (2005). Non-monophyletic taxa and cryptic species-Evidence from a molecular phylogeny of leaf-warblers (Phylloscopus, Aves). Molecular phylogenetics and evolution 36(2): 261-76. doi: 10.1016/j.ympev.2005.01.012.

16. Chatterjee A, Adhikari S, Barik A, Mukhopadhyay S (2013) The Mid-Winter Assemblage and Diversity Of Bird Populations At Patlakhawa Protected Forest, Coochbehar, West Bengal, India. Ring 35: 31-53. doi:10.2478/ring-2013-0002.

17. Adhurya S, Adhurya S, Singha Roy, U (2019) Rapid degradation of wetlands and its impact on avifauna: A case study from Ambuja Wetland, West Bengal, India. Indian Birds 15: 43-48.

18. Nayak A (2020) Blue Rock-thrush Monticola solitarius pandoo: First record from the southern West Bengal, India. Ela Journal of Forestry and Wildlife 9(2): 657-661.

19. Das S (2017) Delineation of groundwater potential zone in hard rock terrain in Gangajalghati block, Bankura district, India using remote sensing and GIS techniques. Modeling Earth Systems and Environment 3: 1589-1599. doi: 10.1007/s40808-017-0396-7.

20. Ali S, Ripley SD (1987) Compact Handbook of the Birds of India and Pakistan together with those of Bangladesh, Nepal, Bhutan and Sri Lanka. Delhi, Oxford University Press.

21. Grimmett R, Inskipp C, Inskipp T (2011) Birds of the Indian Subcontinent. 2nd Edition. London, Oxford University Press \& Christopher Helm.

22. Graber JW, Graber RR (1983) Feeding rates of warblers in spring. Condor 85: 139-150.

23. Price T (1991) Morphology and ecology of breeding warblers along an altitudinal gradient in Kashmir, India. Journal of Animal Ecology 60: 643-664. doi:10.2307/5303.
24. Batova O (2011) Selection of foraging tactics in leaf warblers (Phylloscopus). Biology Bulletin 38: 259-265. doi: 10.1134/S1062359011030022.

25. Biermann GC, Sealy SG (1982) Parental Feeding of Nestling Yellow Warblers in Relation to Brood Size and Prey Availability. The Auk 99 (2): 332-341. doi: 10.1093/auk/99.2.332.

26. Bibby CJ, Thomas DK (1985) Breeding and diets of the Reed Warbler at a rich and a poor site. Bird Study 32(1): 19-31. doi: 10.1080/00063658509476851.

27. López-Iborra G, Limiñana R, Peñarrubia SG, Pinheiro RT (2005) Diet of Common Chiffchaffs (Phylloscopus collybita) wintering in a wetland in south-east Spain. Revista Catalana d'Ornitologia 21: 29-36.

28. Irwin D, Alström P, Olsson U, Benowitz-Fredericks ZM (2001) Cryptic species in the genus Phylloscopus (Old World leaf warblers). Ibis 143 (2): 233-247. doi: 10.1111/j.1474-919X.2001.tb04479.x.

29. Berryman AJ, Eaton JA (2021) Vocalisations and taxonomy of the Sulawesi Leaf Warbler Phylloscopus sarasinorum complex, including discussion of a novel undescribed taxon from Selayar, Indonesia. Forktail 36: 9096.

30. Martens J (2010) Systematic notes on Asian birds: 72. A preliminary review of the leaf warbler genera Phylloscopus and Seicercus. British Ornithological Club Occasional publications 5: 41-116.

31. Johnson MD, Sherry TW (2001) Effects of food availability on the distribution of migratory warblers among habitats in Jamaica. Journal of Animal Ecology 70: 546560. doi: 10.1046/j.1365-2656.2001.00522.x.

32. Ramachandran C, Peter KV, Gopalakrishnan PK (1980) Drumstick (Moringa oleifera): A multipurpose Indian vegetable. Economic Botany 34: 276-283. doi:10.1007/BF02858648.

33. Parrotta JA (2005) In book: Enzyklopädie der Holzgewächse: Handbuch und Atlas der Dendrologie. Roloff A, Weisgerber H, Lang UM, Stimm B, Schütt P, eds. Weinheim, Germany. Wiley-VCH Verlag GmbH \& Co. KGaA. 1-8. 
This page is intentionally left blank. 